Indexing and Abstracting in Following Databases

1. Bowker: A ProQuest Affiliate

\section{Bowker.}

\section{Crossref}

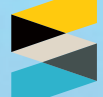

Crossref
Peer Reviewed \& Refereed

Research Trends in Fisheries and Flquatic greiences

\author{
Volume - 11
}

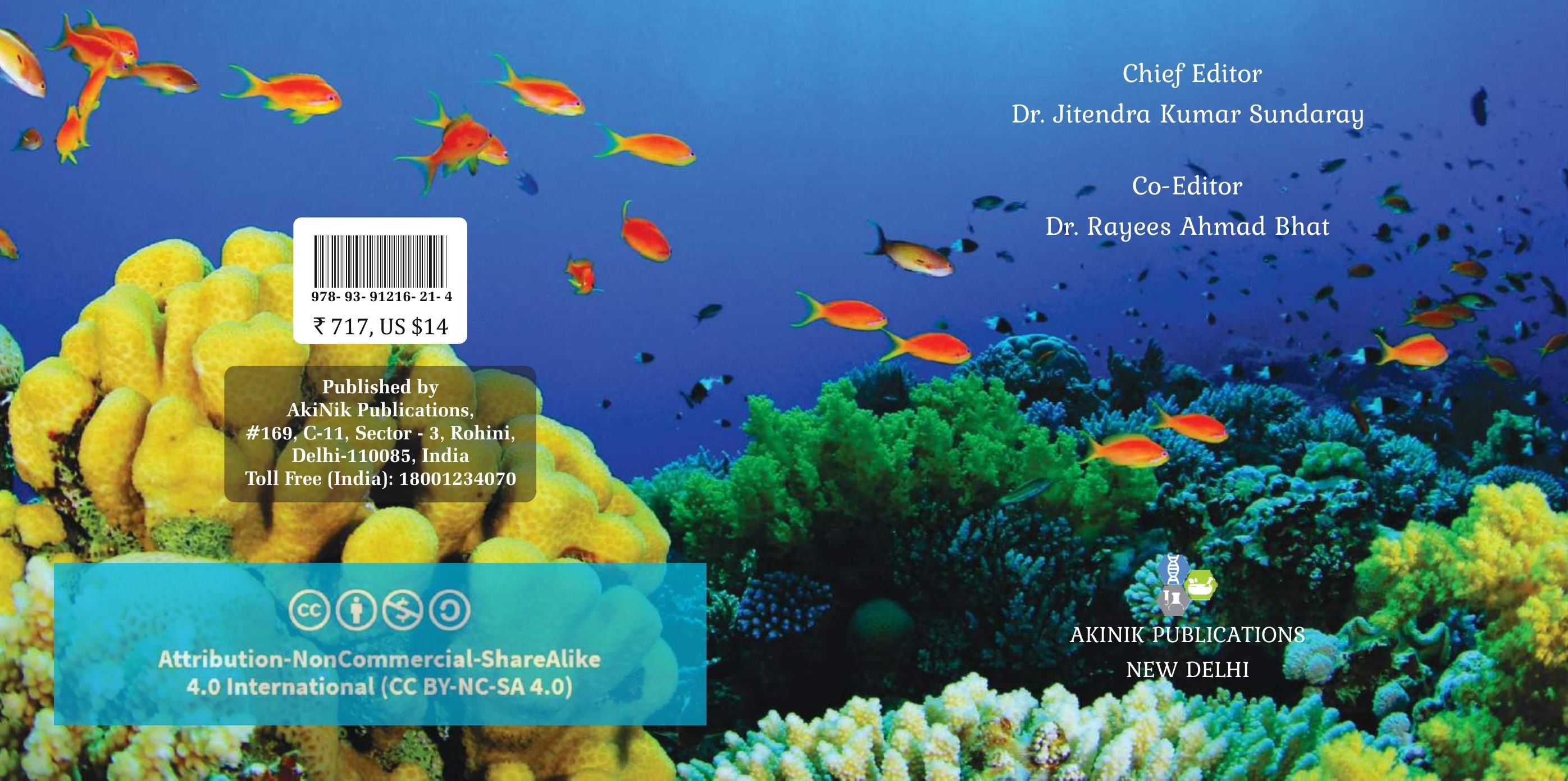




\title{
Research Trends in Fisheries and Aquatic Sciences
}

Volume - 11

\section{Chief Editor}

\section{Dr. Jitendra Kumar Sundaray}

Head, Division of Fish Genetics and Biotechnology at ICAR-Central Institute of Freshwater Aquaculture, Kauaslayaganga, Bhubaneswar, Odisha, India

\author{
Co-Editor \\ Dr. Rayees Ahmad Bhat \\ Department of Zoology, Kurukshetra University, Kurukshetra, Haryana, \\ India
}


Published By: AkiNik Publications
AkiNik Publications
169, C-11, Sector - 3,
Rohini, Delhi-110085, India
Toll Free (India) - 18001234070
Phone No. - 9711224068,9911215212
Email-akinikbooks@gmail.com

Chief Editor: Dr. Jitendra Kumar Sundaray

The author/publisher has attempted to trace and acknowledge the materials reproduced in this publication and apologize if permission and acknowledgements to publish in this form have not been given. If any material has not been acknowledged please write and let us know so that we may rectify it.

(C) AkiNik Publications

Publications Year: 2021

Pages: 157

ISBN: 978-93-91216-21-4

Book DOI: https://doi.org/10.22271/ed.book.1216

Price: ₹ 717/- 


\section{Contents}

Chapters

Page No.

1. Socio-Economic and Household Consumption Expenditures of Small-Scale Fishers between Urban and Rural Coastal Areas 01-18 (Abd. Rahim, Diah Retno Dwi Hastuti, Firmansyah and Ulfah Syam)

2. Live Feeds in Aquaculture

(V. Mohan Raj)

3. Food and Feeding Habit of Freshwater Catfish Mystus dibrugarensis from Upper Brahmaputra Basin, Assam (Dr. Bhenila Bailung)

4. Periphyton: An Emerging Technology to Sustainability in Aquaculture

(Abinaya $P$ )

5. Laboratory Evaluation of Sensitivity of the Freshwater Tropical Worm, Branchiura sowerbyi Beddard, 1892 to Crude Leaf, Bark and Seed Kernel Extracts of Neem (Azadirachta indica A. Juss)

(Kishore Dhara, Prithwish Sarkar, Shubhajit Saha and Himadri Guhathakurta)

6. Wastewater: An Emerging Economic Asset

(M.F. Panthi, N.K. Suyani, R.J. Vasava and Varsha Likhar)

7. Historical Background of Viral Invasions in Aquaculture (R. Dinesh, P. Sivasankar, C. Anand and J. Stephen Sampath Kumar)

8. Community Structure of Benthic Flagellates and Factors Controlling Their Abundance and Distribution along South East Coast of India, Bay of Bengal

(Sangeeta Mishra and Debasish Mahapatro)

9. Updated Systematic Account of Fish Diversity in the Chilika Lagoon (1916 to 2021) with 73 New Records

(Debasish Mahapatro, S.S. Kadam, Sangeeta Mishra, R.K. Mishra and S. Panda) 



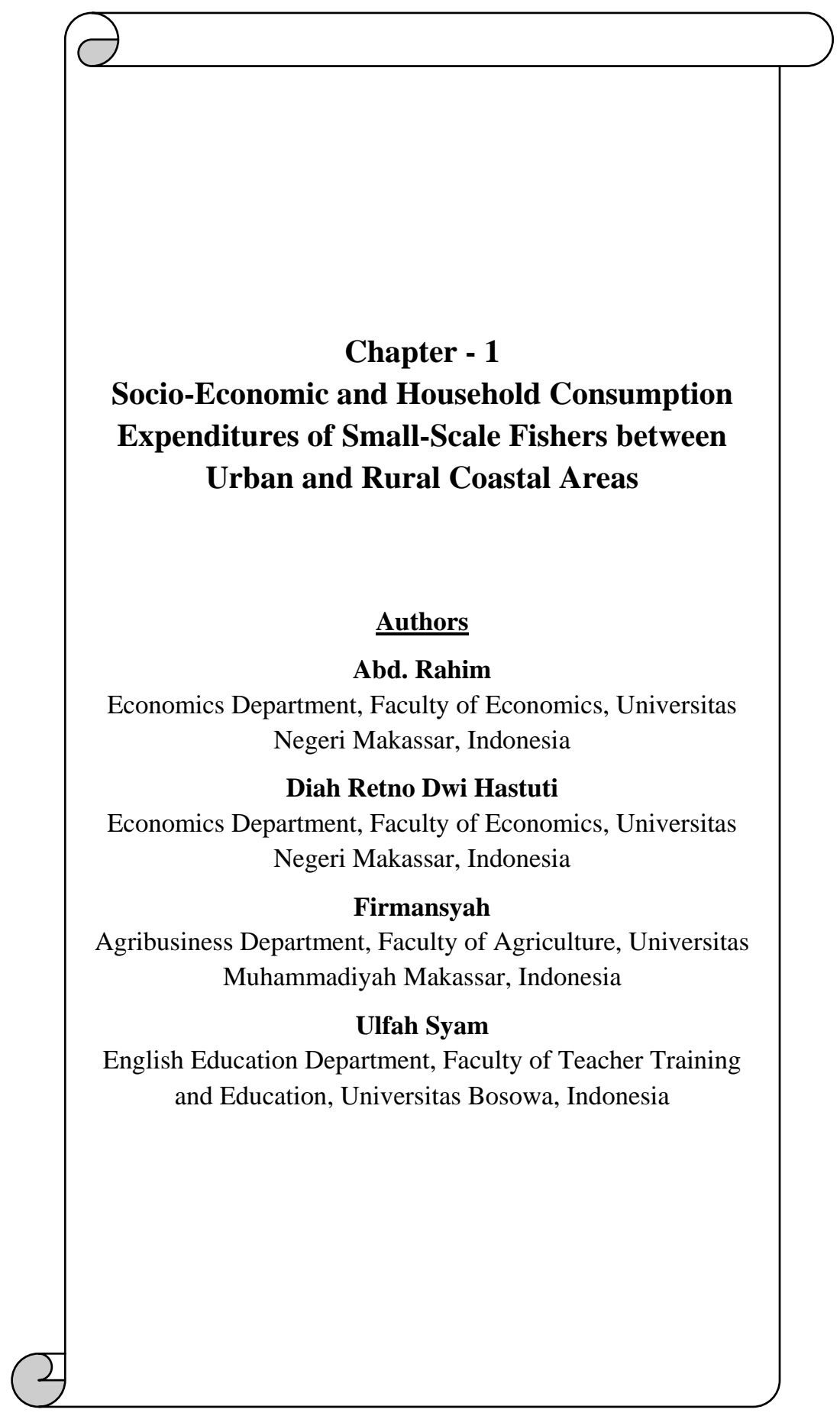


Page | 2 


\title{
Chapter - 1
}

\section{Socio-Economic and Household Consumption Expenditures of Small-Scale Fishers between Urban and Rural Coastal}

Areas

Abd. Rahim, Diah Retno Dwi Hastuti, Firmansyah and Ulfah Syam

\begin{abstract}
Even though the fisher's residence is close together in one coastal area, the changes in small-scale fisher's household expenditures on food and nonfood consumption in coastal areas tend to be different, thus giving decisions on household consumption expenditure the factors that consume them. Research conducted in the west coast area of Makassar City and Takalar District aims to estimate the factors that influence small-scale fishermen's household consumption expenditure. The basic method of research is an explanatory method with multiple linear regression econometric analysis. Respondents of small-scale fishers' households were selected simple random as many as 67 Makassar City and 49 Takalar District. The findings show that food consumption expenditure tends to be greater than that of fishers in Makassar City. On the other hand, fishers in Takalar District have less food consumption than non-food. Small-scale fishermen's food and non-food consumption expenditures in Makassar City are positively influenced by household income, age of fishermen, and the number of family dependents, while the education of fishermen's wives does not have a significant effect. In another case in Takalar District, household income and fisher's wife education do not have a significant effect, while only the fishermen's age and the number of dependents on household consumption expenditures positively affect. Household expenditure can be suppressed from non-food consumption patterns. Food as a source of family nutrition can nourish the body and work to catch more fish so that household consumption expenditure is of higher quality.
\end{abstract}

Keywords: differences in consumption expenditure, small-scale fishers, coastal areas 


\section{Introduction}

Coastal communities have rights to common property resources that provide benefits and efficiency from the sustainability of existing resources [1]. They have a distinctive culture with their dependence on coastal resources in carrying out their economic activities [2]. The household economy is family income and household consumption expenditure ${ }^{[3]}$, which influences coastal communities' welfare ${ }^{[4]}$, mainly small-scale fishermen. In Indonesia, small-scale fishers are dominated by small-scale fishers. 95\% are traditional fishermen with simple fishing gear and have fishing grounds not far from the coast ${ }^{[5]}$. They are characterized as poor and marginalized fishermen ${ }^{[6]}$. However, as a small-scale subsector, fisheries can support the livelihoods and well-being of more than 500 million people worldwide and as an essential source of income in the development of countries ${ }^{[7]}$.

According to ${ }^{[8]}$, every household tries to maximize utility in consuming goods and services with income and price levels as constraints. Household decisions about how much to consume or store are microeconomic questions because they relate to individual economic units ${ }^{[9]}$. Household consumption expenditure is a primary indicator of economic welfare ${ }^{[10]}$ and the most critical component of national income and aggregate demand ${ }^{[11]}$. Household consumption expenditure refers to all goods and services purchased by private households ${ }^{[12]}$ in the amount desired and spent to meet their basic needs such as food, clothing, housing, transportation ${ }^{[9]}$ and certain commodities ${ }^{[13]}$.

Household consumption expenditure of small-scale fishers on the west coast in urban areas (Makassar City) and rural areas (Takalar District) tends to be irrational in its management compared to the fishermen's living conditions. However, Takalar District is directly adjacent to Makassar City as the capital of South Sulawesi province. However, fisher's household expenditures in Takalar District tend to focus more on non-food consumption than fishers households in Makassar City, focusing more on food consumption. Changes in consumption patterns every year affect it. Economically, changes in consumption expenditure are influenced by changes in income ${ }^{[14]}$, while changes in household consumption expenditures are influenced by age, income, marital status, insurance, and household size ${ }^{[15]}$.

Research on fishermen's household consumption expenditures has been carried out in many countries, such as the impact of co-management on 
fisheries household income and spending in Bangladesh ${ }^{[16]}$. The assessing household expenditure of fishers in India ${ }^{[17]}$. Food consumption patterns among rural fishery households for poverty alleviation in North Central Nigeria ${ }^{[18]}$. Comparison of fishermen's household economic situation in Chumphon Province (Thailand) at any given time based on the location of marine protected areas with the Chumphon Islands Marine National Park ${ }^{[19]}$. Assessing fishermen's poverty is measured from household consumption expenditure in Malaysia ${ }^{[20]}$. Income equality and household expenditure of fishers in the Volta Basin in Ghana ${ }^{[21]}$. However, these findings have not yet discussed the regional differences between cities and regencies in coastal areas regarding the socio-economic (household income, age, education, and number of family members) effects on small-scale fishermen household consumption expenditures using the consumption expenditure function approach.

\section{Study of the research area}

The Makassar City and Takalar District are part of the province of South Sulawesi (Figure 1). Makassar City has 15 Districts, while Takalar District has 9 sub-districts ${ }^{[22]}$. The research area is Tamalate Sub-District, Bayombong Village and Galesong Sub-District, Mappakalompo Village, each directly adjacent to the West Coast Coastal area.

Astronomically, Makassar City is located between $119^{\circ} 24^{\prime} 17^{\prime} 38^{\prime}$ East Longitude and $5^{\circ} 8^{\prime} 6^{\prime} 19^{\prime}$ South Latitude ${ }^{[23]}$, while Takalar District is located between $5^{\circ} 30^{\prime}-5^{\circ} 38^{\prime}$ South Latitude and $119^{\circ} 22^{\prime}-119^{\circ} 39^{\prime}$ East Longitude [24]. The area of Takalar District is $566.61 \mathrm{~km}^{2}$, or a percentage of the province's area of $1.21 \%$, while Makassar City, as the capital of South Sulawesi province, is $199.26 \mathrm{~km}^{2}$ or $0.43 \%$. The provincial capital distance is $45 \mathrm{~km}$ to Takalar District, while Makassar City is only $5 \mathrm{~km}{ }^{[22]}$.

Based on geographical position, Makassar City has regional boundaries, namely the north (bordering Maros District), the south (Gowa District), the west (Makassar Strait), and south (Maros District). The boundaries of Takalar District are in the east (Gowa and Jeneponto Districts), north (Gowa District), west (Makassar Strait), and south (Flores Sea) (Badan Pusat Statistik Provinsi Sulawesi Selatan,2020). In the research area, especially Tamalate District, Makassar City has boundaries located in the North (Mariso, Mamajang and Rappocini Sub-Districts), South (Gowa District), South (Takalar District), and West (Makassar Strait) ${ }^{[23]}$. Furthermore, Galesong Sub-District, Takalar District, is located in the north (Galesong Utara Sub-District), East (Gowa District), south (South Galesong District), and west (Makassar Strait) ${ }^{[24]}$. 
Climate Makassar City and Takalar District have tropical climatic conditions, which are tropical monsoon climate, this is indicated by the contrast of the average amount of rainfall in the rainy season and the dry season. Makassar City has a rainy season that usually lasts from November to March and the dry season lasts from May to September with an average annual rainfall ranging from 2,700-3,200 $\mathrm{mm}$. In another case, Takalar District has the rainy season between November and April, and the dry season in October and August with an average annual rainfall ranging from $2,300-3,100 \mathrm{~mm}^{[22]}$.
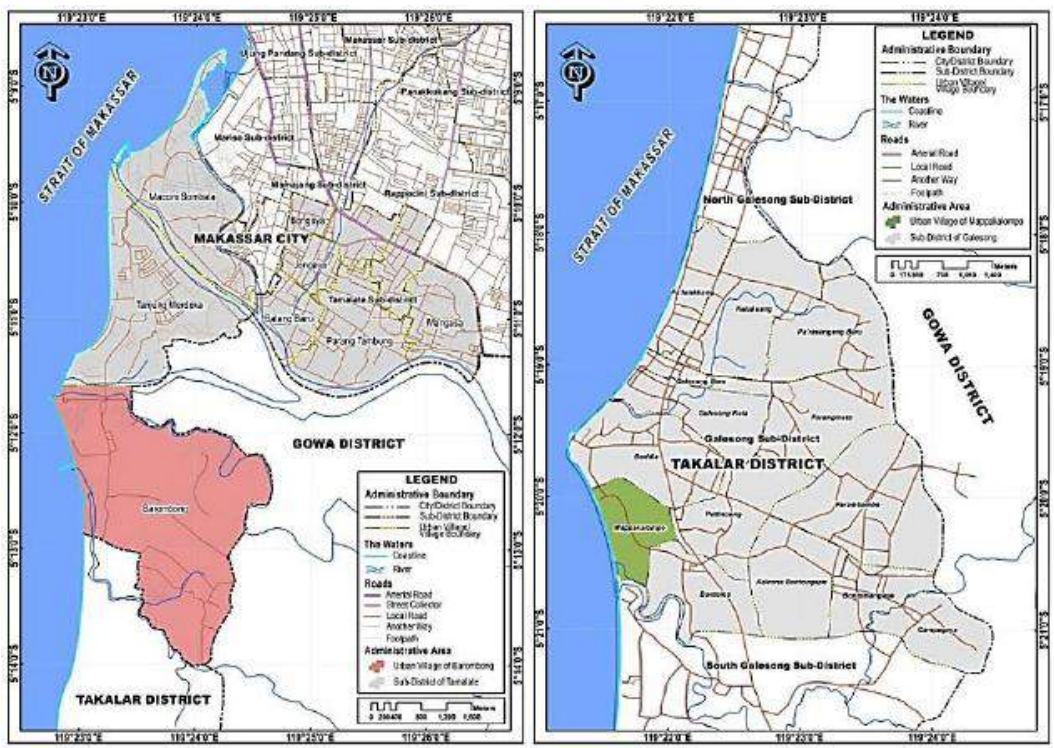

Fig 1: Map of Makassar City and Takalar District, Province South Sulawesi, Indonesia

\section{Household consumption expenditure function}

This research was conducted on the West Coast, South Sulawesi Province, Indonesia, especially Takalar District (Galesong Sub-district, Mappakalompo Village) and Makassar City (Tamalate Sub-District, Bayombong Village). Based on the time dimension using cross-section data sourced from primary data. The sample of respondents consisted of 49 fisher's household from Takalar District and 67 from Makassar City. The research method used is explanatory by estimating the comparison of smallscale fishermen's dwellings to the factors that influence household consumption expenditure.

The fishermen's household consumption expenditure function is proxied by the consumption expenditure function. The specification of the 
econometric model of the Keynesian consumption function is a positive relationship between consumption expenditure and income mathematically written as follows:

$$
C=\beta_{0}+\beta_{1} Y
$$

Where: $C$ is consumption expenditure, $\beta_{0}$ is intercept, $\beta_{1}$ is regression coefficient or model parameter or slope, $\mathrm{Y}$ is income. Furthermore, the uncertainty relationship between economic variables is used by the econometric model in equation (1) to become

$$
C=\beta_{0}+\beta_{1} Y+\mu
$$

Where: $\mu$ is a disturbance error and a random (stochastic) variable with probability properties and characteristics. Based on equation (2), estimation of the factors that affect the household consumption expenditure of smallscale fishers using the multiple regression equation estimation model is as follows:

$$
\begin{aligned}
& \text { CHESCFMC }=\beta_{0} \pi \operatorname{SCF}^{\beta 1} \operatorname{AgSCF}^{\beta 2} \operatorname{EdWf}^{\beta 3} \mathrm{QFM}^{\beta 4 \mu 1} \\
& \text { CHESCFTD }=\beta_{5} \pi \mathrm{SCF}^{\beta 6} \operatorname{AgSCF}^{\beta 7} \operatorname{EdWf}^{\beta 8} \mathrm{QFM}^{\beta 9 \mu 2}
\end{aligned}
$$

Furthermore, to facilitate the calculation of equations (3) and (4), the double log equation or natural logarithm is used as follows:

$$
\mathrm{CHESCFMC}=\beta_{0}+\beta_{1} \pi \mathrm{SCF}+\beta_{2} \mathrm{AgSCF}+\beta_{3} \mathrm{EdWf}+\beta_{4} \mathrm{QFM}+\mu_{1}
$$

$$
\operatorname{CHESCFTD~}=\beta_{5}+\beta_{6} \pi \mathrm{SCF}+\beta_{7} \mathrm{AgSCF}+\beta_{8} \mathrm{EdWf}+\beta_{9} \mathrm{QFM}+\mu_{2}
$$

Where CHESCFMC is the household consumption expenditure of Small-scale fisherman of Makassar City (IDR). CHESCFTD is the household consumption expenditure of Small-scale fisherman of Takalar District (IDR). $\beta_{0}$ and $\beta_{5}$ is the intercept. $\beta_{1} \ldots, \beta_{4}$ and $\beta_{5}, \ldots, \beta_{9}$ is the regression coefficient. $\pi \mathrm{SCF}$ : household income of small-scale fishermen (IDR). AgSCF is the age of small-scale fishermen (year). EdWf is fishermen's wife's education (years). QFM is the number of dependent family members (people).

\section{Socio-economic and household consumption expenditure}

The socio-economic household of small-scale fishers in the West coast area consists of household income, age of fishermen, education of fishermen's wife, and the number of family members. Small-scale fishermen household income derived from fishing and non-fishing business income. 
The household income of fishers in Takalar District is higher than that of Makassar City. This occurs because fishing and non-fishing businesses' income is higher, even though the number of fishers is smaller in Takalar District (Table 1). The fishing business's revenue comes from revenue (catch production and fish prices) less operating costs per trip. Non-capture business income comes from other businesses (business processing and preserving catch fish and raising chickens). The age of small-scale fishers between 30-39 years is the largest age who are still actively working, especially fishermen, with 52 people in Makassar City and Takalar District. Age 20-29 years and $60 \geq$ years are the lowest numbers of those still actively working. There is still 60 years of age as a fisherman because he still supports his family members, especially his children's wife, and grandchildren. The fishers wife's education consists of not completing elementary school, elementary school, lower secondary school, and high school.

The most education of coastal fishermen's wives is that 30 people $(44.78 \%)$ have not graduated from elementary school in Makassar City and Takalar District 31 people (63.26\%) have graduated from elementary school. So, on average, women fishermen on the west coast still have a low level of education. The number of family members carried is quite low in the coastal areas of Makassar City (1-3 people or $67.16 \%$ ) compared to the coastal districts of Takalar District (4-6 people or 69.39\%). This is because fishers households in Makassar city have realized a big responsibility if they look after many children. 
Table 1: Socio Economy of Small-Scale Fishers Household on the West Coast of South Sulawesi, Indonesia

\begin{tabular}{|c|c|c|c|c|c|}
\hline Socio-economic & Description & \multicolumn{2}{|c|}{ Makassar City } & \multicolumn{2}{|c|}{ Takalar District } \\
\hline $\begin{array}{c}\text { Household } \\
\text { Income (IDR) }\end{array}$ & $\begin{array}{l}\text { Capture Business } \\
\text { Income }\end{array}$ & \multicolumn{2}{|c|}{$1,543,423$} & \multicolumn{2}{|c|}{$1,878,450$} \\
\hline & $\begin{array}{l}\text { Non-Capture } \\
\text { Income }\end{array}$ & \multicolumn{2}{|c|}{75,373} & \multicolumn{2}{|c|}{544,907} \\
\hline & Household Income & \multicolumn{2}{|c|}{$1,618,796$} & \multicolumn{2}{|c|}{$2,423,357$} \\
\hline & & Frequency & Percentage & Frequency & Percentage \\
\hline Fishers Age & $20-29$ & 5 & 7.46 & 3 & 6.12 \\
\hline \multirow[t]{4}{*}{ (years) } & $30-39$ & 32 & 47.77 & 20 & 40.48 \\
\hline & $40-49$ & 20 & 29.85 & 21 & 42.86 \\
\hline & $50-59$ & 8 & 11.94 & 1 & 2.04 \\
\hline & $60 \geq$ & 2 & 2.98 & 4 & 8.16 \\
\hline \multirow[t]{2}{*}{ Total } & & 67 & 100.00 & 49 & 100.00 \\
\hline & $\begin{array}{c}\text { Didn't Finish } \\
\text { Elementary School }\end{array}$ & 30 & 44.78 & 11 & 22.45 \\
\hline $\begin{array}{l}\text { Fishers wife } \\
\text { education }\end{array}$ & Elementary School & 28 & 41.78 & 31 & 63.26 \\
\hline \multirow[t]{2}{*}{ (years) } & Junior High School & 7 & 10.45 & 7 & 14.24 \\
\hline & Senior High School & 2 & 2.99 & - & - \\
\hline Total & & 67 & 100.00 & 49 & 100.00 \\
\hline $\begin{array}{l}\text { The family } \\
\text { members }\end{array}$ & $1-3$ & 36 & 67.16 & 6 & 12.22 \\
\hline \multirow[t]{2}{*}{ (people) } & $4-6$ & 19 & 28.36 & 34 & 69.39 \\
\hline & $7-9$ & 3 & 4.48 & 9 & 18.37 \\
\hline Total & & 67 & 100.00 & 49 & 100.00 \\
\hline
\end{tabular}

Small-scale fishers household consumption expenditure in the West Coast tends to be irrational in both Takalar District and Makassar City. The household expenditure of fishers in Takalar District tends to be more towards non-food consumption. The consumption expenditure is IDR 561,333 , which is greater than the food consumption of IDR 411,487 . Nonfood consumption is mostly used for land transportation costs in the form of fuel oil used to reach the city of Takalar District and South Sulawesi province's city or as much as $42.31 \%$ of food consumption. Other non-food items include education fees, electricity, soap, laundry soap, gas stoves, land, and building taxes. Another case in the household expenditure of fishers in Makassar City tends to food consumption. The consumption is IDR 817,030, which is greater than the non-food consumption of IDR 407,234. Cigarette 
foodstuffs are bought quite a lot compared to other foodstuffs (rice, cooking oil, eggs, vegetables, sugar, tea, and coffee) or as much as $35.39 \%$ of nonfood ingredients (Table 2).

Table 2: Household Consumption Expenditure of Small-Scale Fishers in the West Coast of South Sulawesi Province, Indonesia

\begin{tabular}{|c|c|c|c|}
\hline The West Coast Region & Food (IDR) & Non-food (IDR) & Total \\
\hline Makassar City & 817,030 & 407,234 & $1,224,264$ \\
\hline Takalar District & 441,487 & 561,333 & $1,002,821$ \\
\hline Average & $629,258.5$ & $484,283.5$ & $1,113,543$ \\
\hline
\end{tabular}

\section{Socio-economic influence on household consumption expenditures}

The existence of differences in household expenditures for both food consumption and non-food consumption of small-scale fishers in the west coast area is influenced by changes in household income, age of fishermen, and the number of family dependents, while the education of fishermen's wives has no significant effect (Table 3 ). The measurement of the goodness of fit model from the adjusted $\mathrm{R}^{2}$ value shows the independent variable in the estimation model of the household consumption expenditure function of small-scale fishers, which can explain the variation of $65.3 \%$ in Makassar City and $58.2 \%$ in Takalar District. Furthermore, the F-test shows that the factors that simultaneously influence small-scale fishermen's household consumption expenditure have a significant effect because the F-test is 39.487 in Makassar City and 8.418 in Takalar District is greater than the respective F-table. It is different to see the impact partially (t-test) by comparing the $t$ table value. Next, look at each independent variable's changes against the dependent variable with its regression coefficient (Table $3)$.

Household income has a positive effect on household consumption expenditure of small-scale fishers in Makassar City at an error rate of $1 \%$ (0.01) or a confidence level of 99\%. However, it has no significant effect in Takalar District. The expenditure of fishermen's households in Makassar City is mostly for non-food, while fishers in Takalar District are consuming food. Findings in Bangladesh by ${ }^{[16]}$ that the higher the household income level, the smaller the proportion of consumption expenditure on food compared to non-food items. In general, food consumption patterns also tend to be different in each region ${ }^{[26]}$. Found significant differences in diet between rural and urban households. Starchy foods dominate rural diets, whereas animal foods are preferred in urban China. Household income comes from income from catches and non-fishing activities ${ }^{[27]}$. Catch 
production and revenue and cost of catch as income from catch ${ }^{[28]}$ are household income as investment capital, which significantly affects household consumption expenditure decisions ${ }^{[3]}$. However, the dependence of income from fishing businesses is not sufficient for their daily needs, so that other livelihood activities (non-fishing) are urgently needed ${ }^{[29]}$.

Table 3: Comparison of the Socio-Economic Influence on Household Consumption Expenditure of Small-Scale Fishers in the West Coastal Areas South Sulawesi, Indonesia

\begin{tabular}{|c|c|c|c|c|c|}
\hline \multirow{2}{*}{ Independent Variable } & \multirow{2}{*}{ E.S. } & \multicolumn{2}{|c|}{ Makassar City } & \multicolumn{2}{c|}{ Takalar District } \\
\cline { 3 - 6 } & & $\boldsymbol{\beta}$ & t-test & $\boldsymbol{\beta}$ & t-test \\
\hline Household income & + & $0.759^{* * *}$ & 9.010 & $0.021^{\text {ns }}$ & 0.334 \\
\hline Age of small-scale fishermen & + & $0.345^{* *}$ & 3.235 & $0.228^{* * *}$ & 5.597 \\
\hline Fishers wife education & + & $0.762^{\text {ns }}$ & 0.010 & $0.005^{\text {ns }}$ & 1.585 \\
\hline The family members & + & $0.281^{* *}$ & 2.551 & $0.239^{* *}$ & 2.702 \\
\hline Intercept & \multicolumn{3}{|c|}{0.901} & \multicolumn{2}{|c|}{12.259} \\
\hline F-test & \multicolumn{3}{|c|}{39.487} & \multicolumn{2}{|c|}{8.418} \\
\hline Adjusted $\mathrm{R}^{2}$ & \multicolumn{3}{|c|}{0.653} & \multicolumn{3}{|c|}{0.582} \\
\hline $\mathrm{N}$ & \multicolumn{3}{|c|}{67} \\
\hline
\end{tabular}

Note: *** is a level error significance of $1 \%(0,01)$, or confidence level $99 \%$.** is a level error significance of $5 \%(0,05)$, or confidence level $95 \%$. ns is not significant. E.S is an expectation sign.

The age of small-scale fishers has a positive effect on household consumption expenditure in Makassar City and Takalar District's coastal areas. Empirically, the average age of fishers is 30-50 years of fishing. This result is in line with ${ }^{\left[{ }^{30}\right]}$ findings in Taiwan that the age of 40 is the productive age in producing more catches than the age above 50 years. The age of fishers greatly influences fisheries management decisions ${ }^{[31]}$ for their household economy, especially consumption expenditure, both food and non-food. The age structure is an important factor of responsibilities, privileges, rights, and obligations to work ${ }^{[32]}$. Age can affect a person's activities. The older a person is, the longer they work. However, as we get older, working time affects physical strength due to aging [33]. Also, increasing the age of fishers can indicate a long work experience and a significant increase in work in Republic of Korean fishing households ${ }^{[34]}$.

Wife education does not significantly affect small-scale fishers' household consumption expenditure on the west coast of Makassar City and the Takalar District. The average education of fishermen's wives is only Elementary School (E.S.) and Junior High School (JHS). Management of household expenditures is irrational, focusing more on non-food spending 
than food as an essential household need. Education can be used as an investment to increase household economic welfare ${ }^{[35]}$. Women's education can play a role as a rational decision-maker in their household ${ }^{[36]}$, especially their family consumption expenditure [37]. Household expenditure on education (especially children's education) is essential as an investment ${ }^{[38]}$. It can also be used as literacy for fisherwomen to strengthen their bargaining position in the market ${ }^{[39]}$.

The number of family dependents has a positive effect on small fishermen's household consumption expenditure in the two West coast areas. The average number of fisher family dependents in Takalar District is 4-6 people, while Makassar City is 1-3 people. The consumption expenditure of fishing households in the Philippines is determined by the household's size, especially the consumption of rice food ${ }^{[40]}$. In Malaysia, it affects fish food consumption expenditure ${ }^{[41]}$. According to ${ }^{[42]}$, family members are the responsibility of the head of the family, which encourages the spirit of work to increase income and affect household expenses. Consumption expenditure will undoubtedly increase with the increase in the number of family dependents. Savings owned by households will be issued to meet their needs based on the number of dependents ${ }^{[43]}$.

The socio-economic impact on small-scale fishers' household consumption expenditure is significant to become a policy for developing the capture fisheries sector, such as household income, age of fishermen, and several family members. Social, economic, and cultural norms can influence fishermen's decisions ${ }^{[44]}$ in improving their household economy. Changes in food and non-food consumption in households are caused by changes in income from fishing and non-fishing activities. This fishermen's catch should be the point of attention of policymakers such as the government ${ }^{[45]}$ to increase fishing business income during and out of season. Increased catches certainly have an impact on world food security ${ }^{[46]}$ sustainably. The sustainable welfare of small-scale fishers can also reduce poverty ${ }^{[47]}$.

\section{Conclusion}

The household expenditures of small-scale fishermen in the West Coast region have different food and non-food consumption patterns even though they are in the same coastal environment or live nearby. The food consumption pattern is mostly carried out by fishers in Takalar District, while the non-food consumption pattern is fishers in Makassar City. Small scale fishermen's food and non-food consumption expenditures in Makassar City are positively influenced by household income, age of fishers, and some family dependents, while the education of fishermen's wives does not have a 
significant effect. In Takalar District, household income and the teaching of fishermen's wives do not matter. On the other hand, only the fishermen's age and the number of family dependents on household consumption expenditure have a positive effect.

Small-scale fishermen's household expenditure in the west coast region can be reduced, especially the increased non-food consumption pattern because the fishermen's wife's education does not have a significant effect. As the household's financial manager, the wife can focus on the design of food consumption as primary needs rather than secondary or tertiary needs (non-food consumption). Apart from the wife's education, the number of family members impacts household expenditure changes, so that food consumption patterns are more concerned. Through counseling, food can be used as a source of nutrition for fishermen's families to nourish the body so that they are active in catching more fish so that household expenses are of higher quality.

\section{References}

1. Ostorm E, Hess C. Private and Common Property Rights, Workshop of Political Theory and Policy Analysis, Indiana University, 2017, 1-116, [Online]. Available: https://dlc.dlib.indiana.edu/dlc/bitstream/handle/10535/3985/W0725_Ostrom_Hess_DLC.pdf? sequence=1\&isAllowed=y.

2. Rahim A, Hastuti DRD, Bustanul N. Estimation of Household Consumption Expenditure of Small-Scale Fishermen in Indonesia, Russ. J Agric. Socio-Economic Sci. 2018; 83(11):375-383. Doi: 10.18551/rjoas.2018-11.45.

3. Michael NY, Munisamy TM, Haron SA, Yin-Fah BC. Human Capital Investment Expenditure of Women in Female-Headed Household in Penisular Malaysia, Asian Soc. Sci., 2010, 6(4). Doi: 10.5539/ass.v6n4p31.

4. Rostin. The effect of economic empowerment of the coastal communities and social capital on coastal community welfare, Int. J Eng. Sci. 2016; 5:12-18. [Online]. Available: http://www.theijes.com/papers/v5-i2/Version-3/C05203012018.pdf.

5. M Sudarmo AP, Baskoro MS, Wiryawan B, Wiyono ES. Characteristics of Coastal Small-Scale Fisheries In Tegal City, Indonesia, Int. J Sci. Technol. Res. 2015; 4(1):85-88. [Online]. Available: https://www.ijstr.org/final-print/jan2015/Social-Economics- 
Characteristics-Of-Coastal-Small-scale-Fisheries-In-Tegal-CityIndonesia.pdf.

6. Asiedu B, Nunoo FKE, Ofori-Danson PK, Sarpong DB, Sumaila UR. Poverty Measurements in Smallscale Fisheries of Ghana: A Step towards Poverty Eradication, Curr. Res. J Soc. Sci. 2013; 5(3):75-90. [Online].

Available: https://www.researchgate.net/publication/236681882_Poverty_Measure ments_in_Smallscale_Fisheries_of_Ghana_A_Step_towards_Poverty_Eradication.

7. Barnes-Mauthe B, Oleson M, Zafindrasilivonona KLL. The total economic value of small-scale fisheries with a characterization of postlanding trends: An application in Madagascar with global relevance, Fish. Res. 2013; 147:175-185. doi: 10.1016/j.fishres.2013.05.011.

8. Carroll CD. A Theory of the Consumption Function, With and Without Liquidity Constraints, J Econ. Perspect. 2001; 15(3):23-45. doi: 10.1257/jep.15.3.23.

9. Honea Z, Marisennayyab S. Determinants of Household Consumption Expenditure in Debremarkos Town, Amhara Region, Ethiopia, Am. Sci. Res. J Eng. Technol. Sci. 2019; 62(1):124-144. [Online]. Available: https://asrjetsjournal.org/index.php/American_Scientific_Journal/article/ view/5230/2029.

10. Moratti M, Natali L. Measuring household welfare: short versus long consumption modules, 2012. [Online]. Available: https://www.unicefirc.org/publications/671-measuring-household-welfare-short-versuslong-consumption-modules.html.

11. Bonsu OC, Muzindutsi P. Macroeconomic determinants of household consumption expenditure in Ghana: A multivariate co-integration approach, Int. J Econ. Financ. Issues. 2017; 7(4):737-745. [Online]. Available:

https://www.econjournals.com/index.php/ijefi/article/view/3846.

12. Zeynalova Z, Mammadli M. Analysis of the Economic Factors Affecting Household Consumption Expenditures in Azerbaijan, J Crit. Rev., 2020, 7(07). doi: 10.31838/jcr.07.07.40.

13. Barigozzi M, Alessi L, Capasso M, Fagiolo G. The distribution of household consumption-expenditure budget shares, Struct. Chang. Econ. Dyn. 2012; 23(1):69-91. doi: 10.1016/j.strueco.2011.09.003. 
14. Ofwona AC. An Estimation of the Consumption Function for Kenya Using Keynes' Absolute Income Hypothesis for the Period 1992-2011, J Emerg. Trends Econ. Manag. Sci. 2013; 4:103.

15. Caglayan E, Astar M. This paper investigates the determinants of household consumption expenditure in Turkey. It also estimates the models for both rural and urban areas separately to examine the regional gaps for the entire distribution of consumption expenditure. Quantiler, Am. Int. J Contemp. Res. 2012; 2(2):27-34. [Online]. Available: http://acikerisim.demiroglu.bilim.edu.tr:8080/xmlui/handle/11446/419\#s thash.UYxU0T0w.fguKbk3Q.dpbs.

16. Khan MA, Alam MF, Islam KJ. The impact of co-management on household income and expenditure: An empirical analysis of common property fishery resource management in Bangladesh, Ocean Coast. Manag. 2012; 65:67-78. doi: 10.1016/j.ocecoaman.2012.04.014.

17. Marimuthu R, Rajakumar M, Senthilateban R, Radhakrishnan K. Study on Income and Expenditure of Inland Fishermen in Theni Province, India, Econ. Aff. 2015; 60(4):747. doi: 10.5958/09764666.2015.00106.0.

18. Oladimeji Y, Abdulsalam Z, Damisa M, Omokore D. Analysis of Food Consumption Pattern among Rural Fishery Households: A Panacea to Poverty Alleviation in North Central Nigeria, Asian J Agric. Extension, Econ. Sociol. 2015; 6(2):102-110. Doi: 10.9734/AJAEES/2015/17388.

19. Weigel J, Morand P, Mawongwai T, Noël J, Tokrishna R. Assessing economic effects of a marine protected area on fishing households. A Thai case study, Fish. Res. 2015; 161:64-76. doi: 10.1016/j.fishres.2014.06.012.

20. Rhoumah AM. Determinants of factors that affect poverty among coastal fishermen community in Malaysia, J Econ. Financ. 2016; 7(3):913. [Online]. Available: http://www.iosrjournals.org/iosrjef/papers/Vol7-Issue3/Version-2/B0703020912.pdf.

21. Amevenku FKY, Asravor RK. Income equality and household expenditure of fishers in the Volta Basin in Ghana, J Agribus. Dev. Emerg. Econ. 2019; 9(5):552-568. [Online]. Available: https://econpapers.repec.org/article/emejadepp/jadee-03-2019-0030.htm.

22. Badan Pusat Statistik Provinsi Sulawesi Selatan, Provinsi Sulawesi Selatan dalam Angka (Penyedia Data untuk Perencanaan Pembangunan). Sulawesi Selatan: Badan Pusat Statistik Provinsi Sulawesi Selatan, 2020. 
23. Badan Pusat Statistik Kota Makassar, Kota Makassar dalam Angka (Penyedia Data untuk Perencanaan Pembangunan). Kota Makassar: Badan Pusat Statistik Kota Makassar, 2020.

24. Badan Pusat Statistik Kabupaten Takalar, Kabupaten Takalar dalam Angka (Penyedia Data untuk Perencanaan Pembangunan). Kabupaten Takalar, 2020.

25. Gujarati DN, Porter DC. Basic Econometrics (5th edition). McGrawHill, American, 2009.

26. Chai L, Han Z, Liang Y, Su Y, Huang G. Understanding the blue water footprint of households in China from a perspective of consumption expenditure, J Clean. Prod. 2020; 262:121-321. doi: 10.1016/j.jclepro.2020.121321.

27. Rahim A, Hastuti DRD. Applied Multiple Regression Method with Exponential Functions: An Estimation of Traditional Catch Fishermen Household Income, in Journal of Physics: Conference Series. 2018; 1:10-28, 1-8. doi: 10.1088/1742-6596/1028/1/012177.

28. Rahim A, Hastuti DRD, Firmansyah W Sabar, Syam A. The Applied of Cobb-Douglas Production Function with Determinants Estimation of Small-Scale Fishermen's Catches Productions, Int. J Ocean. Oceanogr. 2019; 13(1):81-85. [Online]. Available: https://www.ripublication.com/ijoo19/ijoov13n1_07.pdf.

29. Parashar V, Bara SK, Damde D, Kumar A, Vyas V. Assessment of the socioeconomic status of fishermen communities: a case study from a selected reach of River Narmada, India, Int. J Res. Fish. Aquac. 2016; 6(2):47-59. [Online]. Available: file:///C:/Users/windows 10/Downloads/35_16v6i2_6(1).pdf.

30. Lu Y, Sajiki T, Yagi N. Factors affecting fisherman satisfaction with fishermen's self-governance organizations: A case study of the Taiwan Donggang Sakuraebi (Sergia lucens) production and management group, Mar. Policy. 2020; 115:103-819. doi: 10.1016/j.marpol.2020.103819.

31. Liao C, Huang H, Lu H. Fishermen's perceptions of coastal fisheries management regulations: Key factors to rebuilding coastal fishery resources in Taiwan, Ocean Coast. Manag. 2019; 172:1-13. doi: 10.1016/j.ocecoaman.2019.01.015.

32. Hossain FI, Miah I, All Hosen H, Pervin R, Haque R. Study on the Socio-Economic Condition of Fishermen of the Punorvaba River under Sadar Upazila, Dinajpur, J Fish. 2015; 3(1):239-244. [Online]. Available: https://core.ac.uk/download/pdf/229218381.pdf. 
33. Purwanto H, Rusdarti, Prasetyo PE. The Role of Fishermen Wives in Improving Family Economy in Karangsari, Tuban Sub-District, Tuban Regency, J Econ. Educ. 2020; 9(1):65-72. [Online]. Available: https://journal.unnes.ac.id/sju/index.php/jeec/article/view/37175.

34. Kim T, Park C, Nam J. The determinants of changes in the number of Fishers employed by fisheries household in the Republic of Korea using count data models, Mar. Policy. 2020; 117:103-974. doi: 10.1016/j.marpol.2020.103974.

35. Rabearisoa AL, Zorzi. An economic return to education in small-scale fisheries in North-East Madagascar, West. Indian Ocean J Mar. Sci. 2013; 12(2):185-188. [Online]. Available: https://www.researchgate.net/publication/276930924_An_Economic_Re turn_to_Education_in_Small-scale_Fisheries_in_NorthEast_Madagascar.

36. Osei-Tutu EM, Ampadu E. Dimensions of couples decision-making at home: the ghanian experience, J Int. Womens. Stud. 2018; 19:172-185. [Online].

Available: https://www.researchgate.net/publication/323277943_Dimensions_of_c ouples'_decision-making_at_home_The_Ghanian_experience.

37. Gunakar S, Bhatta R. Socioeconomic Status of Fisher-Women in Segmented Fish Markets of Coastal Karnataka, Agric. Econ. Res. Rev. 2016; 29(2):253. doi: 10.5958/0974-0279.2016.00052.5.

38. Wei H, Guo R, Sun H, Wang N. Household leverage and education expenditure: the role of household investment, Financ. Res. Lett., 2020, 101-837. doi: 10.1016/j.frl.2020.101837.

39. Farooqi FS, RS, Simnani SA. Problems \& prospects of fisherwomen of Kashmir Valley, Int. J Fish. Aquat. Stud. 2018; 6(3):358-360. [Online]. Available:

http://www.fisheriesjournal.com/archives/2018/vol6issue3/PartE/6-315-695.pdf.

40. Palanca-Tan R. Economic Vulnerabilities of Fishing-dependent Households Around Laguna Lake, Philippines, Philipp. J Sci. 2020; 149(3-a):815-829. [Online]. Available: https://www.researchgate.net/publication/344589377_Economic_Vulner abilities_of_Fishingdependent_Households_Around_Laguna_Lake_Philippines. 
41. Tan AKG, Yen ST, Hasan AR. At-Home Consumption of Fish Products in Malaysia: An Analysis of Household Expenditure Survey Data, Mar. Resour. Econ. 2015; 30(4):417-433. doi: 10.1086/682214.

42. Rahim A, Hastuti DRD, Syam U. Estimation Comparison of SmallScale Fisherman Decision on Choice Fishing Gear and Outboard Engine Power, J Eng. Appl. Sci. 2020; 15(2):574-580. doi: 10.36478/jeasci.2020.574.580.

43. Kiran T, Dhawan S. The Impact of Family Size on Savings and Consumption Expenditure of Industrial Workers: A Cross-Sectional Study, Am. J Econ. Bus. Adm. 2015; 7(4):177-184. [Online]. Available: https://www.thescipub.com/pdf/ajebasp.2015.177.184.pdf.

44. Bisack K, Clay PM. Compliance with marine mammal protection: Focus groups reveal factors in commercial fishermen's decisions, Mar. Policy. 2020; 115:103-789. doi: 10.1016/j.marpol.2019.103789.

45. Morzaria-Luna HN et al., Coastal and Marine Spatial Planning in the Northern Gulf of California, Mexico: Consolidating stewardship, property rights and enforcement for ecosystem-based fisheries management, Ocean Coast. Manag. 2020; 197:105-316. Doi: 10.1016/j.ocecoaman.2020.105316.

46. McManus E et al. Commonwealth SIDS and UK Overseas Territories sustainable fisheries programmes: An overview of projects and benefits of official development assistance funding, Mar. Policy. 2019; 107:103437. doi: 10.1016/j.marpol.2019.02.009.

47. Onyango P, Jentoft $\mathrm{S}$. Assessing poverty in small-scale fisheries in Lake Victoria, Tanzania, Fish Fish. 2010; 11(3):250-263. doi: 10.1111/j.14672979.2010.00378.x. 